\title{
The Key Roles of GSK-3 $\beta$ in Regulating Mitochondrial Activity
}

\author{
Kai Yang ${ }^{a}$ Zhixi Chen ${ }^{a}$ Juanjuan Gao Weimei Shi $^{a}$ Linfu Lia, ${ }^{a, d}$ Shan Jiang ${ }^{d}$ \\ Haibo Hua Zhiping Liue Daohua Xub Longhuo $\mathrm{Wu}^{\mathrm{a}}$ \\ aCollege of Pharmacy, Gannan Medical University, Ganzhou, bDepartment of Pharmacology, \\ Guangdong Medical University, Dongguan, 'College of sports and rehabilitation, Gannan Medical \\ University, Ganzhou, dDepartment of academic registry, Beijing University of Chinese Medicine, Beijing, \\ eSchool of Basic Medicine, Gannan Medical University, Ganzhou China
}

\section{Key Words}

Gsk-3ß Mitochondrial biogenesis - Mitochondrial bioenergetics - Mitochondrial permeability $\cdot$ Mitochondrial motility $•$ Mitochondrial apoptosis

\begin{abstract}
:

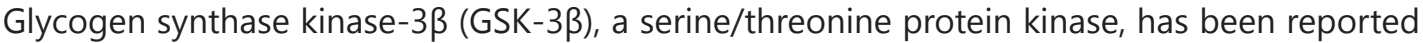
to show essential roles in molecular pathophysiology of many diseases. Mitochondrion is a dynamic organelle for producing cellular energy and determining cell fates. Stress-induced translocated GSK-3 $\beta$ may interact with mitochondrial proteins, including PI3K-Akt, PGC-1 $\alpha$, HK II, PKC $\varepsilon$, components of respiratory chain, and subunits of mPTP. Mitochondrial pool of GSK-3 $\beta$ has been implicated in mediation of mitochondrial functions. GSK-3 $\beta$ exhibits the regulatory effects on mitochondrial biogenesis, mitochondrial bioenergetics, mitochondrial permeability, mitochondrial motility, and mitochondrial apoptosis. The versatile functions of GSK-3 $\beta$ might be associated with its wide range of substrates. Accumulative evidence demonstrates that GSK-3 $\beta$ inactivation may be potentially developed as the promising strategy in management of many diseases, such as Alzheimer's disease (AD) and Parkinson's disease (PD). Intensive

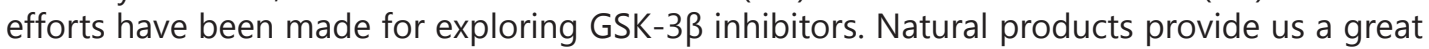
source for screening new lead compounds in inactivation of GSK-3 $\beta$. The key roles of GSK-3 $\beta$ in mediation of mitochondrial functions are discussed in this review.
\end{abstract}

\section{Introduction}

(C) 2017 The Author(s)

Published by S. Karger AG, Basel

GSK-3 has two isoforms $\alpha$ and $\beta$, which have similar biological functions. Most of GSK$3 \beta$ locates in the cytoplasm, and small amounts can be detected in the mitochondria and in the nucleus. But GSK-3 $\alpha$ is not detectable in the mitochondria [1]. It has been demonstrated that the constitutive activity of GSK-3 $\beta$ in the mitochondria and nuclei is much higher for 5-8 folds than that in the cytoplasm in SH-SY5Y cells [2]. In normal myocardium, phosphor-Ser9GSK-3 $\beta$ predominantly locates in the cytosol. In contrast, under stressful conditions, such as

K. Yang, Z. Chen, J. Gao contributed equally to this study

Dr. Daohua Xu

and Dr. Longhuo Wu
College of Pharmacy, Gannan Medical University, Ganzhou (China)

E-Mail daohuax108@163.com / longhwu@hotmail.com

\section{KARGER}


ischemia/reperfusion, phosphor-Ser9-GSK-3 $\beta$ may translocate into mitochondria after 30 min ischemia/30 min reperfusion in rat hearts [3].

Mitochondrion is the sub-organelle to both produce ATP and trigger cell death. GSK-3 $\beta$ signaling plays a critical role in mediating mitochondrial functions. Peroxisome proliferators activated receptor gamma co-activator 1 alpha (PGC-1 $\alpha$ ), known to be the regulatory master in orchestrating mitochondrial biogenesis, has been shown to be mediated by GSK-3 $\beta$ in mitochondria [4]. Phosphor-inactivation of GSK-3 $\beta$ induces the expression of PGC-1-related coactivator (PRC), which is involved in both mitochondrial biogenesis and sensitivity of metabolic stress [5]. Recently, GSK-3 $\beta$ signaling has been demonstrated to be implicated in regulation of mitochondrial permeability transition pore (mPTP) opening, controlling cell fates [6]. In this review, the regulatory effects of GSK-3 $\beta$ on mitochondrial biogenesis, mitochondrial bioenergetics, mitochondrial permeability, mitochondrial motility, and mitochondrial apoptosis are mainly discussed.

\section{The structure and biology of GSK-3 $\beta$}

The two mammalian GSK-3 isoforms: $\alpha$ and $\beta$ have $97 \%$ similarity in sequence. The crystal structure of GSK-3 $\beta$ (Fig. $1 \mathrm{~A}$ ) shows two domain kinase folds: a $\beta$-strand domain formed by residues 25-138 at N-terminus and an $\alpha$-helical domain formed by residues 139-343 at Cterminus. However, the structure of residues 7-24 is invisible, due to no electron density [7]. These residues form a loop to bring phosphor-Ser9 in contact with the basic residues and subsequently prevent against binding a substrate in the groove. The ATP-binding domain locates at the interface of $\beta$-strand and $\alpha$-helical domain. The activation loop ranges from residue 200 to residue 226, running along the groove surface for binding the substrates [8]. This activation loop (Fig. 1B) is well orchestrated to position against the $\alpha$-helical domain. This orientation prepares an available groove for binding a substrate. Thus, phosphorylation of Tyr216 increases the enzymatic activity of GSK-3 $\beta$. The protein structure indicates that GSK-3 $\beta$ favors to phosphorylate at P site in a substrate with SXXXS motif, which has been first phosphorylated at the $[\mathrm{P}+4]$ serine position. Substrates, such as adenomatous polyposis coli protein (APC), eukaryotic initiation fact $2 \mathrm{~b}$ (eIF2b), and GS, are phosphorylated by GSK-3 $\beta$ in the similar manner [9]. However, not all substrates are phosphorylated with the same style/efficiency. Tau, $\beta$-catenin, and Axin are phosphorylated without requiring a prior phosphorylation at $[\mathrm{P}+4]$ serine position. But the phosphorylation efficiency of GSK-3 $\beta$ can increase 50 folds, if phophoserine at $[\mathrm{P}+4]$ position is introduced firstly [9].

Structural modification is closely related to biological function alternations. GSK-3 $\beta$ is a substrate of many signaling pathways, including PI3K/ Akt and insulin. Inhibitory phosphorylation at Ser9 inactivates GSK-3 $\beta$ through Akt signaling, which is also the mechanism for insulin to activate glycogen synthase (GS) [10]. GSK$3 \beta$ has been originally identified as a modulator of glycogen metabolism, and now it is known to regulate various signaling pathways controlling cell fates.

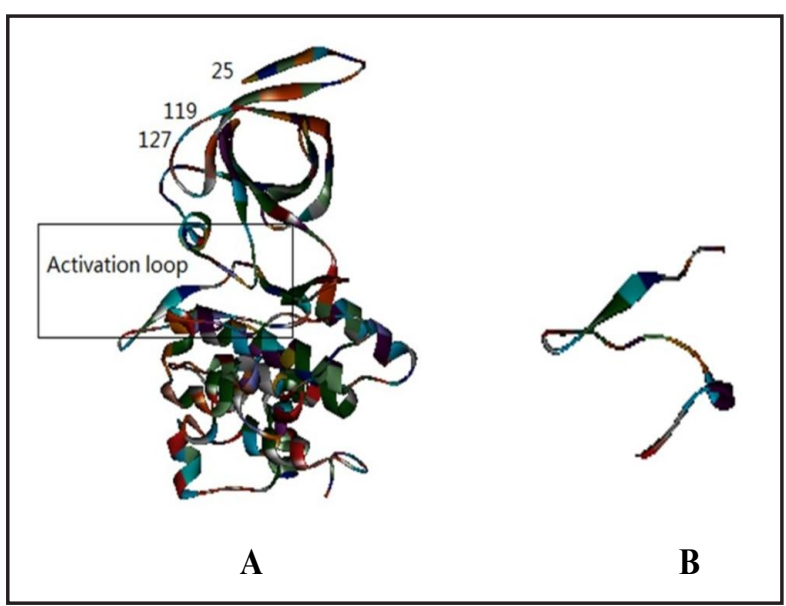

Fig. 1. A: The overall structure of GSK-3 $\beta$ (PDB ID:1I09). The $\mathrm{N}$-terminal domain refers to the $\beta$-strand domain and consists of residue 25-138. The $\alpha$-helical domain consists of residue 139-349. B: The activation loop (residue 200$226)$ of GSK-3 $\beta$ is indicated. 


\section{GSK-3 $\beta$ regulates mitochondrial biogenesis}

The location of GSK-3 $\beta$ in the mitochondria indicates that there are accessible substrates existing in this organelle and regulating mitochondrial metabolism. Increased mass of mitochondrial DNA is often considered as an indication of enhancement in mitochondrial biogenesis. PGC- $1 \alpha$ and mitochondrial transcription factor A (mtTFA) are often used as the markers for evaluating mitochondrial biogenesis. LiCl, a GSK-3 $\beta$ inhibitor, has been demonstrated to exhibit mitochondrial biogenesis by the possible mechanism that LiCl significantly up regulate the expression of PGC- $1 \alpha$ and mtTFA with increase in DNA content in mitochondria, leading to maturation of megakaryocytes [11].

In $\mathrm{C} 2 \mathrm{C} 12$ myotubes, insulin promotes the genes expression of mitofusin 2 protein (Mfn2), mtTFA, mitochondrial single-stranded DNA-binding protein (MtSSB), and nuclear encoded cytochrome $c$ oxidase subunit IV (COX IV), which are the critical factors regulating mitochondrial functions. It has been demonstrated that insulin-dependent mitochondrial biogenesis is regulated by PI3K/Akt signaling through inhibition of GSK-3 $\beta$ [12]. Forkhead box protein 01 (FOX01) promotes the expression of the downstream factor PGC-1 $\alpha$ [13]. However, the activity of PGC-1 $\alpha$ can be repressed by phosphorylated FOXO1 [14]. Insulin reduces the activity of FOXO1 and alters the phosphorylation status of GSK-3 $\beta$ in a PI3K/ Akt signaling-dependent manner. Interestingly, GSK-3 $\beta$ inhibitor LiCl but not SB216763 promotes mitochondrial metabolism activity, including upregulation of Mfn- 2 and COX IV expression [12]. Although GSK-3 $\beta$, FOX01, and PGC- $1 \alpha$ are the three major Akt substrates in mediating glucose metabolism [15], they interact with each other indirectly. GSK-3 $\beta$ may phosphorylate and degrade IRS-1, which acts as an upstream factor of FOXO1. It has been demonstrated that only suppression of Akt/FOXO1 signaling induces insulin resistance. In contrast, PGC- $1 \alpha$-S570A or GSK-3 $\beta$-S9A does not have any effects on insulin sensitivity [15].

It has been shown that GSK-3 $\beta$ acts as a substrate and cleaved by Omi, which is a serine protease mainly in mitochondria and plays a critical role in maintaining the integrity of mitochondria [16]. Omi deficiency causes decreased number of mitochondria, reduced electron density, and decreased expression of mitochondrial components, including COX IV, COX II, Cyt c, and ANT1. These are associated with down-regulation of PGC-1 $\alpha$, which is negatively mediated by GSK-3 $\beta$ through affecting the interaction of SCF-Cdc4 E3 ligase complex with PGC-1 $\alpha$. However, the detailed mechanism is still under investigation [4]. Consistently, glucagon-like peptide-1 (GLP-1) and exendin-4 (EX-4) have been shown to promote mitochondrial biogenesis and the expression of anti-oxidants through upregulation of PGC- $1 \alpha$ activity and down-regulation of GSK-3 $\beta$ activity in advanced glycation end products (AGEs)-induced AD. Further, immunoprecipitation assays show that PGC- $1 \alpha$ may physically bind to GSK-3 $\beta$, which is inactivated by phosphorylation at Ser9 induced by GLP-1/Ex-4 in vivo and in vitro. However, deficiency of GLP-1/Ex-4 impairs the association between PGC-1 $\alpha$ and GSK-3 $\beta$ [17].

Histone $\mathrm{H} 2 \mathrm{~A}$ variant $\mathrm{X}(\mathrm{H} 2 \mathrm{AX})$ locates in both nuclei and mitochondria, and it has been demonstrated that $\mathrm{H} 2 \mathrm{AX}$ plays a key role in mitochondrial DNA repair and stability. H2AX deficiency exhibits mitochondrial defects with alternations in morphology and genes expression. In nuclei, H2AX directly binds to DNA for repairing activity. In contrast, in mitochondrial H2AX directly binds to not DNA but TOM20, a component of import machinery in outer membrane of mitochondria, for transporting mitochondrial precursor proteins into the mitochondria [18]. It has been demonstrated that the phosphorylation of histone H2AX-Ser139 to form $\gamma \mathrm{H} 2 \mathrm{AX}$. Akt is the downstream factor and phosphorylated at Thr-308 and Ser-473 by DNA-dependent protein kinase complex (DNA-PKcs) in response to DNA damage. DNA-PKcs directly promotes H2AX phosphorylation and stabilizes $\gamma \mathrm{H} 2 \mathrm{AX}$, and GSK-3 $\beta$ inactivation prolongs the time of $\gamma \mathrm{H} 2 \mathrm{AX}$ elevation [19]. Co-immunoprecipitation assays show that GSK-3 $\beta$ and TOM20 are both new substrates of E3 ligase SCF ${ }^{\mathrm{Fbx} 07}$ using a high-throughput, cell-independent proteomic approach. SCF ${ }^{\mathrm{Fbx} 07}$ ubiquitinates GSK-3 $\beta$ in a K63-dependent manner and Fbxo7 represses its activity. In contrast, Fbxo7 stabilizes TOM20 


\section{Cellular Physiology Cell Physiol Biochem 2017;44:1445-1459 \\ \begin{tabular}{l|l} 
DOI: 10.1159/000485580 & $\begin{array}{l}\text { O 2017 The Author(s). Published by S. Karger AG, Basel } \\
\text { www.karger.com/cpb }\end{array}$
\end{tabular} \\ Yang et al.: Roles of GSK-3 $\beta$ in Mitochondria}

and correlates with its levels [20]. These indicate a connective network that is a novel field for further investigation.

Conversely, it has been demonstrated that GSK-3 $\beta$ inactivation-induced mitochondrial ROS impair chondrocytes proliferation, leading to cell senescence, as indicated by increased expression of p21, increased activity of senescence associated $\beta$-galactosidase (SA- $\beta \mathrm{Gal}$ ), and cell cycle arrest at $S$ phase in chondrocytes. This is also partially related to DNA damage, as shown by increased expression of two markers proteins $\gamma \mathrm{H} 2 \mathrm{AX}$ and GADD $45 \beta$ (growth arrest and DNA damage-inducible protein $45 \beta$ ). In addition, $\mathrm{LiCl}$ induces the protein expression of IKK $\alpha$, which is correlated with the activity of GADD $45 \beta$ [21]. Consistently, GSK$3 \beta$ inactivation is also reported to induce cellular senescence, accompanied by mitochondrial dysfunction [22]. More investigation is needed for further clear elucidation.

\section{GSK-3 $\beta$ regulates mitochondrial motility}

The production of mitochondrial biogenesis is often associated with fission and fusion processes, maintaining optimum functions and health. Prevention of excessive mitochondrial fission is crucial for mitochondrial quality control. Mitochondrial fusion tends to help for functional mitochondria maintenance. The mitochondrial dynamic proteins, including DLP1, Mfn1, Mfn2, MFF, Fis1, and OPA1, regulate mitochondrial fission and fusion [23]. It has been demonstrated that inhibition of p38 MAPK and GSK-3 $\beta$ down-regulates the expression of DLP1 and MFF and reduces mitochondrial fragmentation in cerebral ischemic injury [24]. MAP1B plays a key role in mitochondrial motility through modulation of the stability and dynamics of microtubules. Phosphorylated MAP1B by GSK-3 $\beta$ has been demonstrated to actively bind to microtubule and regulate its dynamics [25].

GSK-3 $\beta$ has been reported to phosphorylate dynein intermediate chain (IC) at S87/ T88 in IC-1B and S88/T89 in IC-2C, which are the key sites for NDEL1 binding domain, leading to reduction of its interacting with NDEL1 [26]. Thus, the interaction of NDEL1 and dynein is negatively regulated by GSK-3 $\beta$. GSK-3 $\beta$ inhibition may promote dynein motility. Insulin, functions for GSK-3 $\beta$ inhibition, promotes dynein-dependent transport in intestinal cells [27]. HDAC6 also plays an important role in mitochondrial trafficking. It has been demonstrated that inhibition of HDAC6 by tubacin significantly increases mitochondrial motility in hippocampal neurons. GSK-3 $\beta$ potentially binds to and phosphorylates HDAC6 at Ser22 residue, resulting in activation of HDAC6 and attenuation of mitochondrial transport [28]. Serotonin (5-HT) modulates the redistribution of energy sources, which indicates regulation of directional mitochondrial movement. It has been found that activation of 5-HT1A receptor regulates mitochondrial movement through activation of Akt/GSK-3 $\beta$ signaling in hippocampal neurons [29].

Endoplasmic reticulum (ER)-mitochondria interactions are associated with axonal transport. VAPB is an ER protein with $\mathrm{N}$ terminus stretching into the cytoplasm. PTPIP51 is anchored in the MOM with $\mathrm{C}$ terminus stretching into the cytoplasm. It has been demonstrated that the segments of both VAPB and PTPIP51 interact with each other, maintaining $\mathrm{Ca}^{2+}$ homeostasis and regulating ER-mitochondria interactions. Overexpression of GSK-3 $\beta$ attenuates VAPB-PTPIP51 interaction [30]. The disruption of GSK-3 $\beta$-dependent VAPB-PTPIP51 interaction has been implicated in amyotrophic lateral sclerosis and frontotemporal dementia (ALS/FTD), which is accompanied by calcium homeostatic imbalance and impairment of ATP production in mitochondria [31]. The biological role of GSK-3 $\beta$ is still controversial. More investigation is still needed.

Mitochondrial trafficking dysfunction has been involved in the pathology of neurodegenerative diseases, including AD and PD. GSK- $3 \beta$ has been implicated in mediation of mitochondrial transport. TRAK1 is a key protein connecting the MOM protein Miro to the molecular motors kinesin and dynein [32]. Inconsistently, GSK-3 $\beta$ has been reported to be required for normal functions of motor proteins kinesin and dynein [33]. GSK-3 $\beta$ physically binds to TRAK1, together with DISC1 and NDE1, to form a complex, promoting mitochondrial 
trafficking in cultured hippocampal neurons [34]. Overexpression of GSK-3 $\beta$ significantly increases motile mitochondria in a Tau protein-dependent manner. However, GSK-3 $\beta$ does not alter mitochondrial velocity or mitochondrial run length [35]. The possible mechanism might be associated the competitive binding of Tau to microtubules with the motor proteins kinesin and dynein in a concentration-dependent manner in neurons [36].

\section{GSK-3 $\beta$ regulates mitochondrial bioenergetics}

Mitochondrial volume homeostasis is important for its functions, which have been mainly implicated in energy production. GSK-3 $\beta$ is involved in modulating the activity of the respiratory chain. Mitochondrial normal endogenous GSK-3 $\beta$ alone is reported not to alter the activity of complex I. However, it is conceivable that upregulation of GSK-3 $\beta$ activity is correlated to suppression of complex I induced by the specific inhibitors rotenone and 1-methyl-4-phenylpyridinium ion (MPP+), leading to reduction of ATP production and activation of caspase-3-dependent apoptosis. GSK-3 $\beta$-induced malfunction of complex I promotes ROS production, which can be completely abrogated by GSK-3 $\beta$ inhibitor LiCl or inhibitor II (Fig. 2) [37]. GSK-3 $\beta$ has been involved in mitochondrial ROS production. Rieske is a subunit of complex III. The deficiency of Rieske abrogates the enzymatic activity of complex III but does not affect other subunits assembly. Rieske knockout also decreases the protein levels of complex I and IV [38]. Antimycin-A (AA) triggers generation of ROS through interacting with the Qi site of the cytochrome bc1 complex in complex III, resulting in inhibiting the activity of complex III. It has been demonstrated that AA-promoted interaction between GSK-3 $\beta$ and Rieske is associated with ROS production in H9c2 and C2C12 cells [39]. $\mathrm{mK}_{\text {ATP }}$ channel activators can promote the inhibitory phosphorylation of GSK- $3 \beta$, attenuate the interaction of GSK-3 $\beta$-Rieske, and decrease ROS generation. GSK-3 $\beta$ inactivation plays a critical role in mediating the activities of complex I, II, III, and IV, which are negatively affected by bupivacaine (Fig. 2). Lipid emulsion (LE) exhibits the cardioprotective activity against the cytotoxicity of bupivacaine in H9c2 cells through Akt/GSK-3 $\beta$ signaling pathway [40].

Complex IV in mitochondrial respiratory chain is the final electron acceptor to transfer the electron to an oxygen molecule, generating $\mathrm{H}_{2} \mathrm{O}$. This complex is the only one not to produce superoxide in mitochondria. However, it is reported that the mitochondrial superoxide can be induced through modulation of the complex IV activity [41]. The subunit $6 \mathrm{~b}$ of complex IV shows high binding affinity to mitochondrial GSK-3 $\beta$, which in turn phosphorylates subunit $6 \mathrm{~b}$ in complex IV. In Mv1Lu cells, TGF $\beta 1$ induces cell senescence via promotion of mitochondrial ROS production. GSK-3 $\beta$ is a downstream factor of TGF $\beta 1$ signaling [42]. Inactivation of GSK-3 $\beta$ with phosphorylation at Ser9 is implicated in TGF $\beta 1$ induced cell senescence, which might be association of disruption of complex IV activity [43]. GSK-3 $\beta$ inactivation by $\mathrm{LiCl}$ can be a result of activation of PI3K-Akt signaling, which is recently reported to be linked to activation of enzymes in NADPH oxidase family, leading to enhancement of ROS production [44]. GSK-3 $\beta$ has been known to inhibit the activity of glycogen synthase. LiCl treatment or GSK-3 $\beta$ inactivation can induce increased glycogenesis, which might be associated with cellular senescence and aging [45].

Pyruvate dehydrogenase (PDH) converts pyruvate to acetyl CoA in mitochondria and plays an essential role in glycolytic pathway and tricarboxylic acid cycle (TCA). PDH has been demonstrated to be the substrate for TPKI/GSK-3 $\beta$, which predominantly locate in mitochondria. Activated TPKI/GSK-3 $\beta$ is shown to phosphorylate and suppress PDH, leading to disruption of glucose metabolism [46]. Similar results are obtained in DU145 and PC3 cells [47]. Cardiolipin is an important mitochondrial phospholipid, which is essential for the electron transport chain and ATP production. It has been demonstrated that cardiolipid synthase knockdown significantly decrease the capacity of spare respiration, but does not affect the activity of complex I in hCMEC/D3 cells. The possible compensatory 


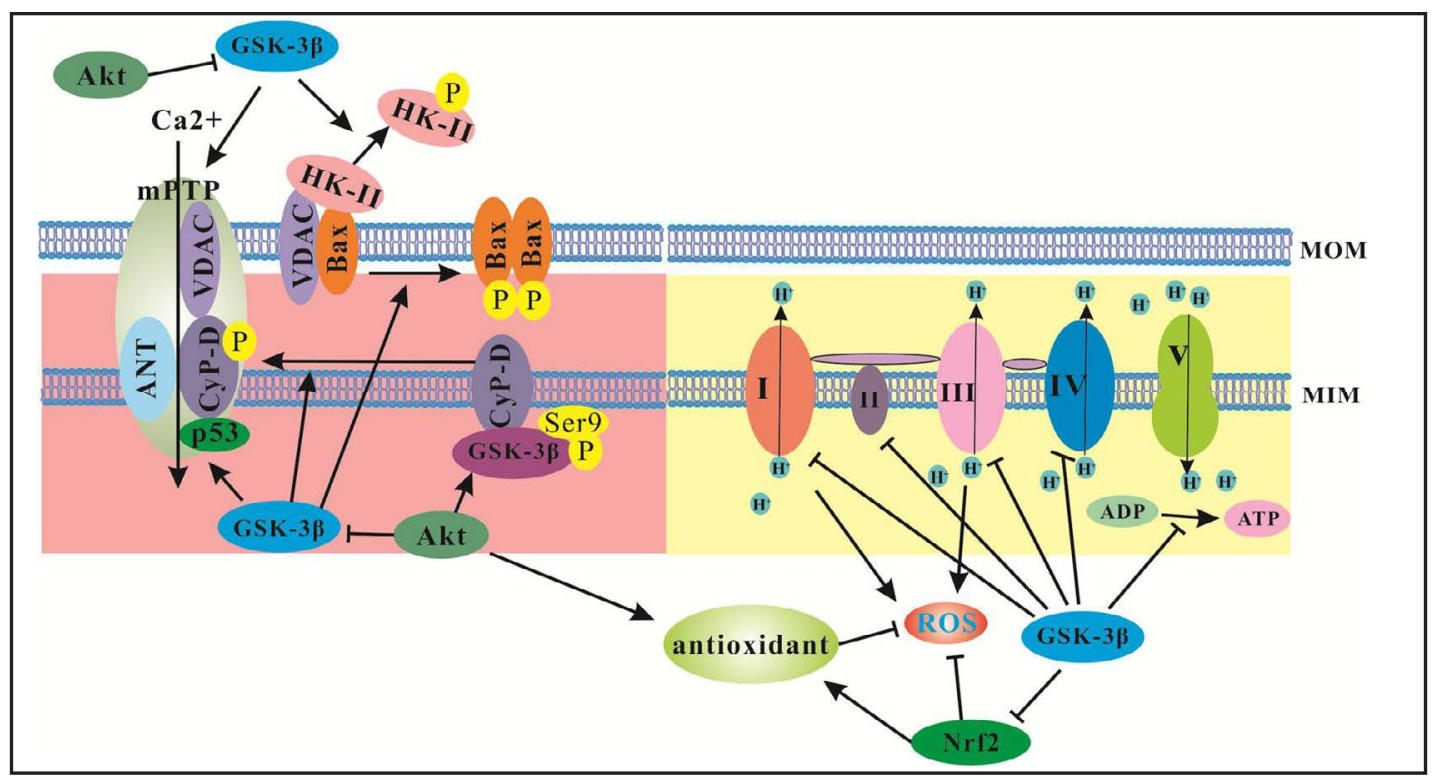

Fig. 2. The effects of GSK-3 $\beta$ on mPTP opening and the respiratory chains. VDAC has anti-apoptotic activity through binding to Bax and HK-II. The release of HK-II initiates the opening of MPTP and activation of aggregation of Bax through the phosphorylation by GSK-3 $\beta$. The inhibitory phosphorylation of GSK-3 $\beta$ Ser9 physically interacts with CyP-D. Inactivation of Akt promotes phosphorylation of CyP-D by active GSK-3 $\beta$, leading to formation of ANT-CyP-D-VDAC and mPTP opening. Calcium overload in mitochondria is triggered through the opened mPTP. GSK-3 $\beta$ significantly inhibits the activity of complex I, II, III, and IV in the respiratory chain, resulting in attenuating ATP production and producing more ROS. In addition, GSK-3 $\beta$ also inhibits the expression of Nrf2 directly or indirectly, which positively increases the capacity of antioxidants system.

mechanism might be associated with increased utilization of glucose, as shown by increased glycolysis and increased activity of pyruvate kinase and GLUT1, which are correlated with inactivation of GSK-3 $\beta$ [48]. GSK-3 $\beta$ inactivation or GSK-3 $\beta$-Ser9 phosphorylation maintains the efficiency of oxidative phosphorylation (OXPHOS) and controls the production of ROS. Ischemic preconditioning (IPC) promotes the concentration of phospho-Ser9-GSK-3 $\beta$ in mitochondria, which directly binds to adenine nucleotide translocator (ANT), resulting in modulation of mitochondrial permeability transition (MPT) functions [49].

\section{GSK-3 $\beta$ regulates mitochondrial permeability}

mPTP, locates in the inner mitochondrial membrane, plays a critical role in cell death. In normal cells, mPTP is closed. MPTP is triggered and opened under stressful conditions, including oxidative stress, $\mathrm{Ca}^{2+}$ overload, increased phosphate concentration, and adenine nucleotide deficiency [50]. Three key components, including ANT, cyclophilin D (CyP-D), and voltage-dependent anion channel (VDAC) form mPTP, which is opened by the binding of CyP-D to ANT [51]. Once opened, any molecule less than 1500 Da can pass through mPTP into mitochondria, leading to the swelling of matrix, disruption of mitochondrial membrane potential $\left(\Delta \Psi_{\mathrm{m}}\right)$, and ATP depletion. CyP-D-ANT interaction decreases the threshold of mPTP in sensitizing $\mathrm{Ca}^{2+}$. Suppression of CyP-D-ANT interaction contributes to attenuation of $\mathrm{mPTP}$ opening (Fig. 2).

The dysregulation of mPTP might be the downstream effects of GSK-3 $\beta$ directly or indirectly. This indicates that phosphor-Ser9-GSK-3 $\beta$ is positively correlated with mPTP opening threshold. Specifically, GSK-3 $\beta$ inhibition decreases the binding of CyP-D to ANT, which interaction can significantly reduce the opening threshold of mPTP (Fig. 2) [6]. Phosphor-Ser9-GSK-3 $\beta$ has been demonstrated to physically interact with ANT 
driven by anesthetic preconditioning (APC) or ischemic preconditioning (IPC) in young cardiomyocytes, but not in the elderly, under oxidative stress, leading to inhibition of CyP-DANT interaction. However, APC and IPC do not facilitate the binding of phosphor-Ser9-GSK$3 \beta$ to VDAC or CyP-D [52]. GSK-3 $\beta$ is a key factor in Wnt signaling, which has been reported to regulate the activity of mPTP [53]. Bcl-2 is the target gene of Wnt signaling to participate in the stabilization of mitochondria against $A \beta$ damage. The possible mechanism might be associated with binding of $\mathrm{Bcl}-2$ to CyP-D [54].

There are three isoforms (VDAC1, VDAC2, and VDAC3) in the mitochondrial outer membrane (MOM), regulating metabolic exchange across MOM. VDAC2, but not VDAC1 or VDAC3, has been reported to physically bind to BAK in the MOM. Under stress, the BH3only proteins such as BIM, BAD, or tBID compete and displace VDAC2 from BAK, initiating cell apoptosis [55]. It has been demonstrated that GSK-3 $\beta$ inhibition delays the opening of mPTP in response to oxidative stress through dephosphorylation of VDAC. This could be associated with reduction of mitochondrial calcium loading, which is forced by $\Delta \Psi_{\mathrm{m}}[56]$. Further studies show that GSK-3 $\beta$ physically interacts with VDAC2 through its N-terminal domain under oxidative stress. Selective knockdown of VDAC2 or kinase-deficiency GSK-3 $\beta$ K15A mutant can significantly suppress the translocation of GSK-3 $\beta$ and mPTP opening in H9c2 cardiomyoblasts [57]. This indicates that mediation of mPTP opening by GSK-3 $\beta$ is VDAC2- and kinase- dependent. In addition, GSK-3 $\beta$ inhibition also promotes the binding affinity of Bcl-2 to mitochondrial VDAC, due to alternation of phosphorylation of VDAC [58].

Hexokinase II (HK-II), existed in MOM, has been reported to be another important mediator for mPTP. Detachment of HK-II from mitochondria may induce mPTP opening and subsequent cell apoptosis. Akt phosphorylates HK-II and promotes it to bind to mitochondria. GSK-3 $\beta$ activation may induce HK-II release from mitochondria, initiating mitochondria-dependent apoptosis (Fig. 2) [59]. HK-II has been demonstrated to mainly dock with VDAC1 at mitochondria [60]. Bax mitochondrial accumulation is positively related to mitochondrial dysfunction and mitochondria-dependent apoptosis. HK-II has been demonstrated to significantly reduce the accumulation of Bax in the mitochondria under metabolic stress [61]. GSK-3 $\beta$ phosphorylates VDAC1 and subsequently promotes it to interact with Bax, resulting in disruption of HK-II and VDAC1 interaction [60]. Furthermore, GSK-3 $\beta$ might be involved in regulation of HK-II mRNA expression induced by benzo [a] pyrene [62]. CyP-D locates in the mitochondrial inner membrane. Deletion of CyP-D has been shown to exhibit significant resistance to oxidative stress and calcium overload [63]. It has been demonstrated that CyP-D is also a phosphorylatable substrate of GSK-3 $\beta$ through directly targeting S38, S39, and S123 residues in CyP-D (Fig. 2). The complex GSK-3 $\beta$-CyP-D facilitates mPTP opening in osteosarcoma SAOS-2 cells [64]. This also provides the evidence of GSK-3 $\beta$ translocation from the cytoplasm to mitochondrion through interacting with VDAC2 and CyP-D [57, 64]. Recently, CyP-D- $\mathrm{F}_{1} \mathrm{~F}_{0}$ ATP synthase interaction has been proposed to be involved in mPTP opening in diabetic mice. Blockade of such interaction provides a novel therapeutic intervention for improving synaptic plasticity, learning, and memory in diabetes [65]. P53 interacts with CyP-D and synergistically regulates the activity of mPTP. The interaction of CyP-D and p53 dictates loss of $\Delta \Psi_{\mathrm{m}}$, release of cytochrome $c$, and activation of apoptosis [66]. GSK-3 $\beta$ with N-terminal 78-92 residues can bind to the C-terminal domain of p53. The phosphorylation of p53 by GSK-3 $\beta$ is essential for its acetylation and subsequent translocation into mitochondria [67]. It has been demonstrated that p53-regulated mPTP opening can be abrogated by GSK-3 $\beta$ inhibition [68].

\section{GSK-3 $\beta$ regulates mitochondria-dependent apoptosis}

GSK-3 $\beta$ has been involved in stress-induced cellular apoptosis. Activated GSK-3 $\beta$ can phosphorylate the downstream substrates, such as p53, Bax, and p21 ${ }^{\text {Cip } 1}$, which are important for determining cell fate. GSK-3 $\beta$ activation is prior to initiation of the caspase cascade correlating to cell apoptosis [69]. GSK-3 $\beta$ is phosphorylated and negatively regulated by many signaling pathways, including PI3K/Akt, PKA, ERK, PKC, p90rsk, and p70S6K, which 
are involved in mediation of mitochondrial activity [70, 71]. GSK-3 $\beta$ is correlated with activation of caspase- 2 and caspase-8, which can induce the cleavage of Bid and the release of cytochrome $c$, leading to mitochondrial dysfunction and apoptosis. It has been demonstrated that inhibitory phosphorylation of GSK-3 $\beta$-Ser9 attenuates ceramide-induced mitochondrial apoptosis through inactivating caspase- 2 and caspase- 8 [72, 73]. Mcl-1, an anti-apoptotic member of Bcl-2 family, stabilizes mitochondrial outer membrane permeabilization through sequestering Bak- or Bax-activating proteins Bim and Bid. Mcl-1 can be phosphorylated at S159 by GSK-3 $\beta$ and recognized for ubiquination and degradation $[74,75]$.

Sarco/endoplasmic reticulum (SR/ER) is also a key player during cell death. It has been found that GSK-3 $\beta$ is also located in mitochondria-associated ER membrane (MAMs) and SR/ER, physically associating with IP3Rs $\mathrm{Ca}^{2+}$ channeling. Inhibition of GSK-3 $\beta$ significantly reduces the formation of complex and impairs SR/ER calcium release into mitochondria at reperfusion in cardiomyocytes, leading to amelioration of calcium overload in mitochondria and subsequent cell apoptosis [76]. However, RyR-related calcium release is not affected by GSK-3 $\beta$, and GSK-3 $\beta$ inhibition does not modify calcium-induced $\Delta \Psi_{\mathrm{m}}$ [76]. Homeostasis of $\Delta \Psi_{\mathrm{m}}$ is important for cell viability. Loss of $\Delta \Psi_{\mathrm{m}}$ induced by dysregulation of mPTP leads to disruption of ATP synthesis, morphological swellness, and initiation of cell apoptosis in mitochondria. It has been demonstrated that inactivation of GSK-3 $\beta$ facilitates the recovery of $\Delta \Psi_{\mathrm{m}}$ partially and exhibits cytoprotective activity in H9c2 and C2C12 cells through activation of $\mathrm{mK}_{\text {ATP }}$ channel, which is ATP-dependent [39].

Oxidative stress is also involved in mPTP opening. NF-E2-related factor (Nrf2), a master regulator of antioxidant response, is negatively regulated by GSK-3 $\beta$. GSK-3 $\beta$ inactivation and Nrf2 upregulation by salidroside have been reported to inhibit mPTP opening, leading to decrease of ROS production, suppression of cytochrome $c$ release, and inhibition of caspase activation [77]. Oxidative stress-induced mPTP opening can be reversed dose-dependently by tauroursodeoxycholic acid (TUDCA), an ER stress inhibitor, through activation of PI3KAkt-GSK-3 $\beta$ signaling, resulting in cardioprotection against I/R injury and cell death [78].

However, the pro-apoptotic activity of GSK- $3 \beta$ is controversial. GSK-3 $\beta$ is also required for cell survival through mediating NF- $\kappa B$ signaling. GSK-3 $\beta$ knockout mouse embryos can't survive, due to severe liver degeneration induced primarily by cellular apoptosis [10]. In addition, GSK-3 $\beta$ may mediate cellular growth and differentiation [79]. This might be associated with its broad range of substrates. Further efforts are needed for clear elucidation.

\section{Natural compounds regulate mitochondrial activity through GSK-3 $\beta$}

Natural compounds are featured as their structural diversity and being a good source for exploring lead compounds for the potential therapeutics in modulating the activity of GSK-3 $\beta$ (Table 1). Curcumin, a natural versatile compound from Curcuma longa, has been shown to improve the mitochondrial functions, decrease mitochondrial oxidative stress, and prevent cell apoptosis through activation of Akt/GSK-3 $\beta$ signaling in Saos- 2 cells [80]. Resveratrol, the most famous polyphenol, significantly alleviates MPP+-induced mitochondrial dysfunctions through activation of Akt-GSK-3 $\beta$ signaling in SN4741 cells [81]. Proanthocyanidins, an effective free radical scavenger, ameliorates anoxia-reoxygenation injury through activation of PI3K-Akt-GSK-3 $\beta$ signaling pathway and $\mathrm{mK}_{\text {ATP }}$ channel pathway in myocardial cells [82]. Asiatic acid, a pentacyclic triterpenoid isolated from Centella asiatica, exhibits protective effects against myocardial I/R injury, as indicated by improved mitochondrial functions through Akt-GSK-3 $\beta$-HIF- $1 \alpha$ signaling in hypoxic H9c2 cells [83].

Triptolide has been shown to potentially exhibit anti-inflammatory and autoimmunesuppressive activities, accompanied by severe toxicities, such as cardiac and liver damage [84]. It has been demonstrated that selective inhibition of GSK-3 $\beta$ by SB216763 may significantly ameliorate the adverse effects of triptolide in H9c2 cells through inhibition of CyP-D phosphorylation and modulation of Bcl-2 family proteins, leading to desensitization of mPTP and prevention of mitochondrial apoptosis [85]. Formononetin, a natural isoflavone from Radix Astragali, has been reported to activate Akt/GSK-3 $\beta$ signaling in H9c2 cells.

\section{KARGER}


Formononetin also promotes the binding of phosphor-Ser9-GSK-3 $\beta$ of ANT and disruption of the complex formation of CyP-D-ANT, leading to abolishment of MPTP opening and reduction of ROS generation [86].

Hesperidin (a flavanone glycoside) has been reported to improve the deficits of learning and memory, upregulate the capacity of anti-oxidant system, and enhance the enzyme activities of mitochondrial complex I-IV through inhibition of GSK-3 $\beta$ activity [87]. Similarly, liquiritin, a main component of Glycyrrhiza Radix, also alleviates mitochondrial apoptotic alternations induced by glutamate predominantly through activation of ERK and Akt-GSK$3 \beta$ signaling pathways [88]. Neurotoxin 6-hydroxydopamine (6-OHDA) induces initiation of mitochondria-regulated apoptotic cascade events in SH-SY5Y cells, which can be ameliorated by the administration of sulfuretin through inhibition of GSK-3 $\beta$ signaling and inactivation of NF- $\kappa B$ signaling [89]. Baicalein, isolated from Scutellaria baicalensis Georgi, increases mitochondrial phosphorylation of Akt-Thr308 and GSK-3 $\beta$-Ser9, resulting in prevention of cytochrome $c$ release in primary cultured chick cardiomyocytes [90].

\section{Clinical prospective}

Currently, LiCl have been employed for treating Alzheimer disease. Valproic acid exhibits to promote hair growth through inhibition of GSK-3 $\beta$ activity and stabilization of $\beta$-catenin [91]. In addition, enzastaurin (LY317615) has been developed as an inhibitor of PKC $\beta$ to reduce GSK-3 $\beta$ activity through inhibiting GSK-3 $\beta$ phosphorylation at phase I and II in clinical tests [92]. Accumulative evidences indicate that GSK-3 $\beta$ has been implicated in mitochondrial functions. Rosuvastatin postconditioning exhibits protective effects against myocardial ischemia-reperfusion injury through induction of Akt and GSK$3 \beta$ phosphorylation and subsequent inhibition of mPTP opening [93]. Prostaglandin E1 (PGE1) has been known to be anti-thrombotic. PGE1 pretreatment significantly improves the cardiological deficits through inactivation of GSK-3 $\beta$-mPTP signaling pathway [94]. Arachidonyl-2-chloroethylamide (ACEA) protects neurons from damage in ischemic injury through selectively activating cannabinoid receptor 1 (CB1R). ACEA effectively increases the volume and number of mitochondria and promotes the expression of mtTFA, NRF1, and COX IV through inhibitory phosphorylation of GSK-3 $\beta$, leading to amelioration of mitochondrial function in cerebral ischemia [95].

GSK-3 $\beta$ has been identified as the modulator of dynamin-related protein 1 (DRP1), which is a GTPase and a key component of the fission machinery in mitochondria responding

Table 1. Natural compounds regulate mitochondrial activity through GSK-3 $\beta$

\begin{tabular}{|c|c|c|}
\hline Compounds & Cell types & Biological activities \\
\hline Curcumin & Saos- 2 cells & $\begin{array}{l}\text { mitochondrial functions } \uparrow \text {, oxidative stress } \downarrow \text {, cell } \\
\text { apoptosis } \downarrow \text {, Akt/GSK-3 } \beta \text { signaling } \uparrow\end{array}$ \\
\hline Resveratrol & SN4741 cells & $\begin{array}{c}\text { MPP+-induced mitochondrial dysfunctions } \downarrow \text {, Akt/GSK- } \\
3 \beta \text { signaling } \uparrow\end{array}$ \\
\hline Proanthocyanidins & myocardial cells & $\begin{array}{c}\text { anoxia-reoxygenation injury } \downarrow \text {, PI3K-Akt-GSK-3 } \beta \\
\text { signaling } \uparrow, \mathrm{mK}_{\mathrm{ATP}} \text { channel pathway } \uparrow\end{array}$ \\
\hline Asiatic acid & H9c2 cells & $\begin{array}{l}\text { I/R injury } \downarrow \text {, mitochondrial functions } \uparrow, \text { Akt-GSK-3 } \beta \text {-HIF- } \\
1 \alpha \text { signaling } \uparrow\end{array}$ \\
\hline Triptolide & H9c2 cells & $\begin{array}{c}\text { CyP-D phosphorylation } \downarrow \text {, desensitization of mPTP } \uparrow \text {, } \\
\text { mitochondrial apoptosis } \downarrow\end{array}$ \\
\hline Formononetin & H9c2 cells & $\begin{array}{l}\text { Akt/GSK-3 } \beta \text { signaling } \uparrow \text {, phosphor-Ser9-GSK-3 } \beta \text {-ANT } \uparrow \text {, } \\
\text { CyP-D-ANT } \downarrow, \text { mPTP opening } \downarrow \text {, ROS generation } \downarrow\end{array}$ \\
\hline Hesperidin & $\begin{array}{l}\text { APPswe/PS1dE9 } \\
\text { transgenic mice }\end{array}$ & $\begin{array}{c}\text { learning and memory } \uparrow \text {, capacity of anti-oxidant } \\
\text { system } \uparrow \text {, activities of mitochondrial complex I-IV } \uparrow, \text { GSK- } \\
3 \beta \text { activity } \downarrow\end{array}$ \\
\hline liquiritin & differentiated PC12 cells & $\begin{array}{c}\text { mitochondrial apoptosis } \downarrow, \text { ERK and Akt-GSK-3 } \beta \\
\text { signaling } \uparrow\end{array}$ \\
\hline Sulfuretin & SH-SY5Y cells & $\begin{array}{c}\text { apoptotic cascade } \downarrow \text {, GSK-3 } \beta \text { signaling } \downarrow, N F-\kappa B \\
\text { signaling } \downarrow\end{array}$ \\
\hline Baicalein & $\begin{array}{l}\text { primary cultured chick } \\
\text { cardiomyocytes }\end{array}$ & 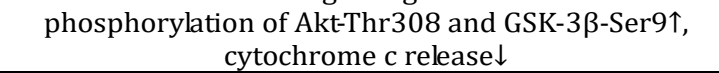 \\
\hline
\end{tabular}


Fig. 3. The biological effects of GSK-3 $\beta$ in mitochondrial metabolism. As it indicates, GSK-3 $\beta$ inactivation promotes mitochondrial biogenesis, elevates mitochondrial dynamics, attenuates mitochondrial permeability, and ameliorates mitochondrial apoptosis.

to intraocular pressure (IOP) elevation. GSK-3 $\beta$ inhibition by LiCl significantly reduces mitochondrial fission and cell death through down-regulation of DRP1 in RGC-5 cells [96]. GSK-3 $\beta$ induces DRP1-Ser616 phosphorylation, causing

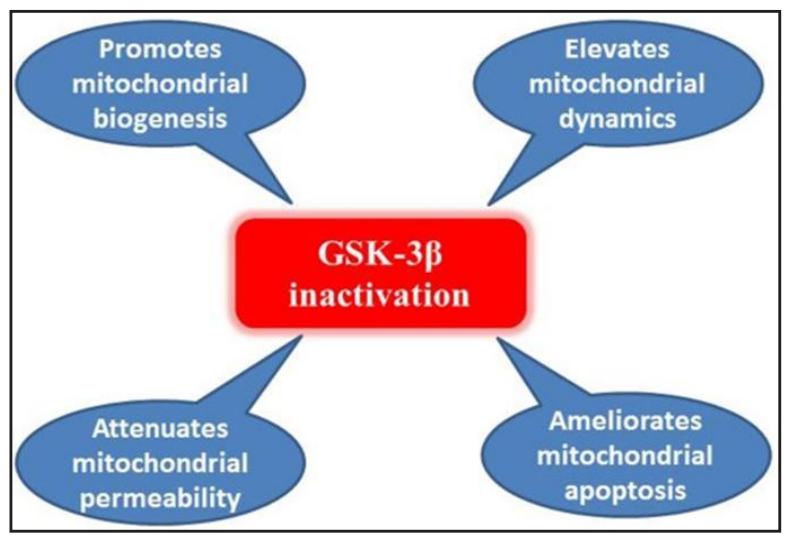
abnormal mitochondrial alternation in fission. GSK-3 $\beta$ inhibition and DRP1 modulation has been reported to ameliorate mitochondrial impairment, which is responsible for synaptic plasticity deficit in diabetic mice [97].

Under the condition of oxygen-glucose deprivation/reperfusion, DRP1 physically binds to GSK-3 $\beta$ for form a complex translocating into mitochondria and dysregulation of mPTP opening, leading to mitochondrial dysfunctions. Ginkgolide K, a natural compound isolated from Ginkgo biloba leaves, exhibits neuroprotective effects through significant attenuation of mitochondrial fission and mPTP opening [98]. Exogenous $\mathrm{H}_{2} \mathrm{~S}$ exhibits protective roles in IPC-induced cardiomyopathy in the aging process by inhibition of MPTP opening through activating PI3K-Akt-GSK-3 $\beta$, ERK1/2-GSK-3 $\beta$, and PKC $\varepsilon-\mathrm{mK}_{\text {ATP }}$ signaling pathways [99]. Mitochondrial PKC $\varepsilon$ antagonizes the effects of PKC $\delta$, which activates GSK-3 $\beta$ and induces mPTP opening under I/R injury. Aldehyde dehydrogenase-2 (ALDH2), a substrate of PKC $\varepsilon$, promotes the translocation of PKC $\varepsilon$ into mitochondria. GSK-3 $\beta$ inhibition ameliorates PKC $\delta$ induced ROS-dependent DRP1 phosphorylation and caspase cascade activation [100].

\section{Conclusion}

Stress-induced translocation of GSK-3 $\beta$ into mitochondria indicates to receive signals and challenges from cytoplasm. Accumulative evidence demonstrates that mitochondrial pool of GSK-3 $\beta$ appears to interact with mitochondrial proteins, including PI3K-Akt, HK II, $\mathrm{PKC} \varepsilon$, components of respiratory chain, and subunits of mPTP. Due to the wide range of substrates, GSK-3 $\beta$ determines the cell fates through modifying the mitochondrial biology. GSK-3 $\beta$ inactivation promotes mitochondrial biogenesis, elevates mitochondrial dynamics, attenuates mitochondrial permeability, and ameliorates mitochondriadependent apoptosis (Fig. 3). GSK-3 $\beta$ inactivation might become the promising strategy for clinical drugs development. Natural products provide us a great source for exploring the potential therapeutics. However, the versatile effects of GSK-3 $\beta$ are still controversial. More investigation is encouraged.

\section{Disclosure Statement}

The authors declare no conflict of interests.

\section{Acknowledgements}

This study was financially supported by the National Science Foundation of China (81660371 and 31560260), the National Science Foundation of Jiangxi Province (20161BAB215219 and 20171BAB215058), and scientific Research Fund of Jiangxi Provincial Education Department (GJJ150949 and GJJ150973). 


\section{Cellular Physiology Cell Physiol Biochem 2017;44:1445-1459 \begin{tabular}{l|l|l} 
and Biochemistry Published online: December 01, 2017 & $\begin{array}{l}\text { (c) } 2017 \text { The Author(s). Published by S. Karger AG, Basel } \\
\text { www.karger.com/cpb }\end{array}$
\end{tabular}}

Yang et al.: Roles of GSK-3 $\beta$ in Mitochondria

\section{References}

1 Hoshi M, Sato M, Kondo S, Takashima A, Noguchi K, Takahashi M, Ishiguro K, Imahori K: Different localization of tau protein kinase I/glycogen synthase kinase-3 beta from glycogen synthase kinase-3 alpha in cerebellum mitochondria. J Biochem 1995;118:683-685.

-2 Bijur GN, Jope RS: Glycogen synthase kinase-3 beta is highly activated in nuclei and mitochondria. Neuroreport 2003;14:2415-2419.

3 Nishihara M, Miura T, Miki T, Tanno M, Yano T, Naitoh K, Ohori K, Hotta H, Terashima Y, Shimamoto K: Modulation of the mitochondrial permeability transition pore complex in GSK-3beta-mediated myocardial protection. J Mol Cell Cardiol 2007;43:564-570.

-4 Xu R, Hu Q, Ma Q, Liu C, Wang G: The protease Omi regulates mitochondrial biogenesis through the GSK3beta/PGC-1alpha pathway. Cell Death Dis 2014;5:e1373.

5 Gleyzer N, Scarpulla RC: Concerted Action of PGC-1-related Coactivator (PRC) and c-MYC in the Stress Response to Mitochondrial Dysfunction. J Biol Chem 2016;291:25529-25541.

6 Juhaszova M, Zorov DB, Kim SH, Pepe S, Fu Q, Fishbein KW, Ziman BD, Wang S, Ytrehus K, Antos CL, Olson EN, Sollott SJ: Glycogen synthase kinase-3beta mediates convergence of protection signaling to inhibit the mitochondrial permeability transition pore. J Clin Invest 2004;113:1535-1549.

7 ter Haar E, Coll JT, Austen DA, Hsiao HM, Swenson L, Jain J: Structure of GSK3beta reveals a primed phosphorylation mechanism. Nat Struct Biol 2001;8:593-596.

8 Hanks SK, Quinn AM: Protein kinase catalytic domain sequence database: identification of conserved features of primary structure and classification of family members. Methods Enzymol 1991;200:38-62.

-9 Thomas GM, Frame S, Goedert M, Nathke I, Polakis P, Cohen P: A GSK3-binding peptide from FRAT1 selectively inhibits the GSK3-catalysed phosphorylation of axin and beta-catenin. FEBS Lett 1999;458:247251.

10 Hoeflich KP, Luo J, Rubie EA, Tsao MS, Jin O, Woodgett JR: Requirement for glycogen synthase kinase-3beta in cell survival and NF-kappaB activation. Nature 2000;406:86-90.

-11 Undi RB, Gutti U, Gutti RK: LiCl regulates mitochondrial biogenesis during megakaryocyte development. J Trace Elem Med Biol 2017;39:193-201.

-12 Litwiniuk A, Pijet B, Pijet-Kucicka M, Gajewska M, Pająk B, Orzechowski A: FOXO1 and GSK-3beta Are Main Targets of Insulin-Mediated Myogenesis in C2C12 Muscle Cells. PLoS One 2016;11:e146726.

13 Puigserver P, Rhee J, Donovan J, Walkey CJ, Yoon JC, Oriente F, Kitamura Y, Altomonte J, Dong H, Accili D, Spiegelman BM: Insulin-regulated hepatic gluconeogenesis through FOX01-PGC-1alpha interaction. Nature 2003;423:550-555.

14 Sajan M, Hansen B, Ivey RR, Sajan J, Ari C, Song S, Braun U, Leitges M, Farese-Higgs M, Farese RV: Brain Insulin Signaling Is Increased in Insulin-Resistant States and Decreases in FOXOs and PGC-1alpha and Increases in Abeta1-40/42 and Phospho-Tau May Abet Alzheimer Development. Diabetes 2016;65:18921903.

15 Sakai G, Inoue I, Suzuki T, Sumita T, Inukai K, Katayama S, Awata T, Yamada T, Asano T, Katagiri H, Noda M, Shimada A, Ono H: Effects of the activations of three major hepatic Akt substrates on glucose metabolism in male mice. Endocrinology 2017;158:2659-2671

-16 Kang S, Louboutin JP, Datta P, Landel CP, Martinez D, Zervos AS, Strayer DS, Fernandes-Alnemri T, Alnemri ES: Loss of HtrA2/Omi activity in non-neuronal tissues of adult mice causes premature aging. Cell Death Differ 2013;20:259-269.

17 An FM, Chen S, Xu Z, Yin L, Wang Y, Liu AR, Yao WB, Gao XD: Glucagon-like peptide-1 regulates mitochondrial biogenesis and tau phosphorylation against advanced glycation end product-induced neuronal insult: Studies in vivo and in vitro. Neuroscience 2015;300:75-84.

-18 Jeong JH, Cheol KY, Piao Y, Kang S, Pak YK: miR-24-mediated knockdown of H2AX damages mitochondria and the insulin signaling pathway. Exp Mol Med 2017;49:e313.

19 An J, Huang YC, Xu QZ, Zhou LJ, Shang ZF, Huang B, Wang Y, Liu XD, Wu DC, Zhou PK: DNA-PKcs plays a dominant role in the regulation of $\mathrm{H} 2 \mathrm{AX}$ phosphorylation in response to DNA damage and cell cycle progression. BMC Mol Biol 2010;11:18.

-20 Teixeira FR, Randle SJ, Patel SP, Mevissen TE, Zenkeviciute G, Koide T, Komander D, Laman H: Gsk3beta and Tomm20 are substrates of the SCFFbxo7/PARK15 ubiquitin ligase associated with Parkinson's disease. Biochem J 2016;473:3563-3580. 


\section{Cellular Physiology Cell Physiol Biochem 2017;44:1445-1459 \begin{tabular}{l|l|l} 
DOI: 10.1159/000485580 & $\begin{array}{l}\text { O 2017 The Author(s). Published by S. Karger AG, Basel } \\
\text { www.karger.com/cpb }\end{array}$
\end{tabular}}

Yang et al.: Roles of GSK-3 $\beta$ in Mitochondria

-21 Guidotti S, Minguzzi M, Platano D, Cattini L, Trisolino G, Mariani E, Borzì RM: Lithium Chloride Dependent Glycogen Synthase Kinase 3 Inactivation Links Oxidative DNA Damage, Hypertrophy and Senescence in Human Articular Chondrocytes and Reproduces Chondrocyte Phenotype of Obese Osteoarthritis Patients. PLoS One 2015;10:e143865.

22 Kim YM, Seo YH, Park CB, Yoon SH, Yoon G: Roles of GSK3 in metabolic shift toward abnormal anabolism in cell senescence. Ann N Y Acad Sci 2010;1201:65-71.

-23 Chan DC: Fusion and fission: interlinked processes critical for mitochondrial health. Annu Rev Genet 2012;46:265-287.

-24 Zhang XM, Zhang L, Wang G, Niu W, He Z, Ding L. Jia J: Suppression of mitochondrial fission in experimental cerebral ischemia: The potential neuroprotective target of p38 MAPK inhibition. Neurochem Int 2015;90:18.

25 Meli R, Weisova P, Propst F: Repulsive axon guidance by Draxin is mediated by protein Kinase B (Akt), glycogen synthase kinase-3beta (GSK-3beta) and microtubule-associated protein 1B. PLoS One 2015;10:e119524.

26 Gao FJ, Hebbar S, Gao XA, Alexander M, Pandey JP, Walla MD, Cotham WE, King SJ, Smith DS: GSK-3beta Phosphorylation of Cytoplasmic Dynein Reduces Ndel1 Binding to Intermediate Chains and Alters Dynein Motility. Traffic 2015;16:941-961.

27 Gao FJ, Shi L, Hines T, Hebbar S, Neufeld KL, Smith DS: Insulin signaling regulates a functional interaction between adenomatous polyposis coli and cytoplasmic dynein. Mol Biol Cell 2017;28:587-599.

-28 Chen S, Owens GC, Makarenkova H, Edelman DB: HDAC6 regulates mitochondrial transport in hippocampal neurons. PLoS One 2010;5:e10848.

29 Chen S, Owens GC, Crossin KL, Edelman DB: Serotonin stimulates mitochondrial transport in hippocampal neurons. Mol Cell Neurosci 2007;36:472-483.

-30 Stoica R, De Vos KJ, Paillusson S, Mueller S, Sancho RM, Lau KF, Vizcay-Barrena G, Lin WL, Xu YF, Lewis J, Dickson DW, Petrucelli L, Mitchell JC, Shaw CE, Miller CC: ER-mitochondria associations are regulated by the VAPB-PTPIP51 interaction and are disrupted by ALS/FTD-associated TDP-43. Nat Commun 2014;5:3996.

-31 Stoica R, Paillusson S, Gomez-Suaga P, Mitchell JC, Lau DH, Gray EH, Sancho RM, Vizcay-Barrena G, De Vos KJ, Shaw CE, Hanger DP, Noble W, Miller CC: ALS/FTD-associated FUS activates GSK-3beta to disrupt the VAPB-PTPIP51 interaction and ER-mitochondria associations. EMBO Rep 2016;17:1326-1342.

32 Ogawa F, Malavasi EL, Crummie DK, Eykelenboom JE, Soares DC, Mackie S, Porteous DJ, Millar JK: DISC1 complexes with TRAK1 and Miro1 to modulate anterograde axonal mitochondrial trafficking. Hum Mol Genet 2014;23:906-919.

-33 Dolma K, Iacobucci GJ, Hong ZK, Shandilya J, Toska E, White JA 2nd, Spina E, Gunawardena S: Presenilin influences glycogen synthase kinase-3 beta (GSK-3beta) for kinesin-1 and dynein function during axonal transport. Hum Mol Genet 2014;23:1121-1133.

-34 Ogawa F, Murphy LC, Malavasi EL, O’Sullivan ST, Torrance HS, Porteous DJ, Millar JK: NDE1 and GSK3beta Associate with TRAK1 and Regulate Axonal Mitochondrial Motility: Identification of Cyclic AMP as a Novel Modulator of Axonal Mitochondrial Trafficking. ACS Chem Neurosci 2016;7:553-564.

-35 Llorens-Martin M, Lopez-Domenech G, Soriano E, Avila J: GSK3beta is involved in the relief of mitochondria pausing in a Tau-dependent manner. PLoS One 2011;6:e27686.

-36 Dixit R, Ross JL, Goldman YE, Holzbaur EL: Differential regulation of dynein and kinesin motor proteins by tau. Science 2008;319:1086-1089.

-37 King TD, Clodfelder-Miller B, Barksdale KA, Bijur GN: Unregulated mitochondrial GSK3beta activity results in NADH: ubiquinone oxidoreductase deficiency. Neurotox Res 2008;14:367-382.

-38 Diaz F, Enriquez JA, Moraes CT: Cells lacking Rieske iron-sulfur protein have a reactive oxygen speciesassociated decrease in respiratory complexes I and IV. Mol Cell Biol 2012;32:415-429.

-39 Sunaga D, Tanno M, Kuno A, Ishikawa S, Ogasawara M, Yano T, Miki T, Miura T: Accelerated recovery of mitochondrial membrane potential by GSK-3beta inactivation affords cardiomyocytes protection from oxidant-induced necrosis. PLoS One 2014;9:e112529.

40 Lv D, Bai Z, Yang L, Li X, Chen X: Lipid emulsion reverses bupivacaine-induced apoptosis of h9c2 cardiomyocytes: PI3K/Akt/GSK-3beta signaling pathway. Environ Toxicol Pharmacol 2016;42:85-91. 


\section{Cellular Physiology Cell Physiol Biochem 2017;44:1445-1459 \begin{tabular}{l|l|l}
\hline and BOI: 10.1159/000485580 & $\begin{array}{l}\text { C } 2017 \text { The Author(s). Published by S. Karger AG, Basel } \\
\text { www.karger.com/cpb }\end{array}$ \\
\hline
\end{tabular}}

Yang et al.: Roles of GSK-3 $\beta$ in Mitochondria

41 Yoon YS, Lee JH, Hwang SC, Choi KS, Yoon G: TGF beta1 induces prolonged mitochondrial ROS generation through decreased complex IV activity with senescent arrest in Mv1Lu cells. Oncogene 2005;24:18951903.

42 Rahimi RA, Leof EB: TGF-beta signaling: a tale of two responses. J Cell Biochem 2007;102:593-608.

43 Byun HO, Jung HJ, Seo YH, Lee YK, Hwang SC, Hwang ES, Yoon G: GSK3 inactivation is involved in mitochondrial complex IV defect in transforming growth factor (TGF) beta1-induced senescence. Exp Cell Res 2012;318:1808-1819.

44 Nakanishi A, Wada Y, Kitagishi Y, Matsuda S: Link between PI3K/AKT/PTEN Pathway and NOX Proteinin Diseases. Aging Dis 2014;5:203-211.

45 Seo YH, Jung HJ, Shin HT, Kim YM, Yim H, Chung HY, Lim IK, Yoon G: Enhanced glycogenesis is involved in cellular senescence via GSK3/GS modulation. Aging Cell 2008;7:894-907.

46 Hoshi M, Takashima A, Noguchi K, Murayama M, Sato M, Kondo S, Saitoh Y, Ishiguro K, Hoshino T, Imahori K: Regulation of mitochondrial pyruvate dehydrogenase activity by tau protein kinase I/glycogen synthase kinase 3beta in brain. Proc Natl Acad Sci U S A 1996;93:2719-2723.

47 Fu YM, Lin H, Liu X, ang W, Meadows GG: Cell death of prostate cancer cells by specific amino acid restriction depends on alterations of glucose metabolism. J Cell Physiol 2010;224:491-500.

48 Nguyen HM, Mejia EM, Chang W, Wang Y, Watson E, On N, Miller DW, Hatch GM: Reduction in cardiolipin decreases mitochondrial spare respiratory capacity and increases glucose transport into and across human brain cerebral microvascular endothelial cells. J Neurochem 2016;139:68-80.

-49 Duarte FV, Amorim JA, Varela AT, Teodoro JS, Gomes AP, Cunha RA, Palmeira CM, Rolo AP: Adenosine receptors: regulatory players in the preservation of mitochondrial function induced by ischemic preconditioning of rat liver. Purinergic Signal 2017;13:179-190.

50 Halestrap AP: What is the mitochondrial permeability transition pore? J Mol Cell Cardiol 2009;46:821-831.

51 Miura T, Nishihara M, Miki T: Drug development targeting the glycogen synthase kinase-3beta (GSK-3beta)mediated signal transduction pathway: role of GSK-3beta in myocardial protection against ischemia/ reperfusion injury. J Pharmacol Sci 2009;109:162-167.

52 Zhu J, Rebecchi MJ, Glass PS, Brink PR, Liu L: Interactions of GSK-3beta with mitochondrial permeability transition pore modulators during preconditioning: age-associated differences. J Gerontol A Biol Sci Med Sci 2013;68:395-403.

53 Arrazola MS, Ramos-Fernandez E, Cisternas P, Ordenes D, Inestrosa NC: Wnt Signaling Prevents the Abeta Oligomer-Induced Mitochondrial Permeability Transition Pore Opening Preserving Mitochondrial Structure in Hippocampal Neurons. PLoS One 2017;12:e168840.

54 Eliseev RA, Malecki J, Lester T, Zhang Y, Humphrey J, Gunter TE: Cyclophilin D interacts with Bcl2 and exerts an anti-apoptotic effect. J Biol Chem 2009;284:9692-9699.

55 Cheng EH, Sheiko TV, Fisher JK, Craigen WJ, Korsmeyer SJ: VDAC2 inhibits BAK activation and mitochondrial apoptosis. Science 2003;301:513-517.

-56 Ruiz-Meana M, Garcia-Dorado D, Miro-Casas E, Abellán A, Soler-Soler J.: Mitochondrial Ca2+ uptake during simulated ischemia does not affect permeability transition pore opening upon simulated reperfusion. Cardiovasc Res 2006;71:715-724.

-57 Tanno M, Kuno A, Ishikawa S, Miki T, Kouzu H, Yano T, Murase H, Tobisawa T, Ogasawara M, Horio Y, Miura T: Translocation of glycogen synthase kinase-3beta (GSK-3beta), a trigger of permeability transition, is kinase activity-dependent and mediated by interaction with voltage-dependent anion channel 2 (VDAC2). J Biol Chem 2014;289:29285-29296.

58 Das S, Wong R, Rajapakse N, Murphy E, Steenbergen C: Glycogen synthase kinase 3 inhibition slows mitochondrial adenine nucleotide transport and regulates voltage-dependent anion channel phosphorylation. Circ Res 2008;103:983-991.

59 Rasola A, Sciacovelli M, Pantic B, Bernardi P: Signal transduction to the permeability transition pore. FEBS Lett 2010;584:1989-1996.

60 Gimenez-Cassina A, Lim F, Cerrato T, Palomo GM, Diaz-Nido J: Mitochondrial hexokinase II promotes neuronal survival and acts downstream of glycogen synthase kinase-3. J Biol Chem 2009;284:3001-3011.

61 Gall JM, Wong V, Pimental DR, Havasi A, Wang Z, Pastorino JG, Bonegio RG, Schwartz JH, Borkan SC: Hexokinase regulates Bax-mediated mitochondrial membrane injury following ischemic stress. Kidney Int 2011;79:1207-1216. 


\section{Cellular Physiology Cell Physiol Biochem 2017;44:1445-1459 \begin{tabular}{l|l|l}
\hline and Biochemistry 10.1159/000485580 & $\begin{array}{l}\text { C) } 2017 \text { The Author(s). Published by S. Karger AG, Basel } \\
\text { www.karger.com/cpb }\end{array}$ \\
\hline
\end{tabular}}

Yang et al.: Roles of GSK-3 $\beta$ in Mitochondria

-62 Dendele B, Tekpli X, Sergent O, Dimanche-Boitrel MT, Holme JA, Huc L, Lagadic-Gossmann D: Identification of the couple GSK3alpha/c-Myc as a new regulator of hexokinase II in benzo [a]pyrene-induced apoptosis. Toxicol in Vitro 2012;26:94-101.

63 Baines CP, Kaiser RA, Purcell NH, Blair NS, Osinska H, Hambleton MA, Brunskill EW, Sayen MR, Gottlieb RA, Dorn GW, Robbins J, Molkentin JD: Loss of cyclophilin D reveals a critical role for mitochondrial permeability transition in cell death. Nature 2005;434:658-662.

64 Rasola A, Sciacovelli M, Chiara F, Pantic B, Brusilow WS, Bernardi P: Activation of mitochondrial ERK protects cancer cells from death through inhibition of the permeability transition. Proc Natl Acad Sci U S A 2010;107:726-731.

65 Yan S, Du F, Wu L, Zhang Z, Zhong C, Yu Q, Wang Y, Lue LF, Walker DG, Douglas JT, Yan SS: F1F0 ATP Synthase-Cyclophilin D Interaction Contributes to Diabetes-Induced Synaptic Dysfunction and Cognitive Decline. Diabetes 2016;65:3482-3494.

66 Qin LS, Jia PF, Zhang ZQ, Zhang SM: ROS-p53-cyclophilin-D signaling mediates salinomycin-induced glioma cell necrosis. J Exp Clin Cancer Res 2015;34:57.

67 Eom TY, Jope RS: GSK3 beta N-terminus binding to p53 promotes its acetylation. Mol Cancer 2009;8:14.

68 Miura T, Tanno M: Mitochondria and GSK-3beta in cardioprotection against ischemia/reperfusion injury. Cardiovasc Drugs Ther 2010;24:255-263.

69 Bijur GN, Jope RS: Proapoptotic stimuli induce nuclear accumulation of glycogen synthase kinase-3 beta. J Biol Chem 2001;276:37436-37442.

70 Jope RS, Johnson GV: The glamour and gloom of glycogen synthase kinase-3. Trends Biochem Sci 2004;29:95-102.

71 Zhang C, Liu S, Yuan X, Hu Z, Li H, Wu M, Yuan J, Zhao Z, Su J, Wang X, Liao Y, Liu Q: Valproic Acid Promotes Human Glioma U87 Cells Apoptosis and Inhibits Glycogen Synthase Kinase-3beta Through ERK/Akt Signaling. Cell Physiol Biochem 2016;39:2173-2185.

72 Lin CF, Chen CL, Chiang CW, Jan MS, Huang WC, Lin YS: GSK-3beta acts downstream of PP2A and the PI 3-kinase-Akt pathway, and upstream of caspase-2 in ceramide-induced mitochondrial apoptosis. J Cell Sci 2007;120:2935-2943.

73 Lin CF, Tsai CC, Huang WC, Wang YC, Tseng PC, Tsai TT, Chen CL: Glycogen Synthase Kinase-3beta and Caspase-2 Mediate Ceramide- and Etoposide-Induced Apoptosis by Regulating the LysosomalMitochondrial Axis. PLoS One 2016;11:e145460.

74 Maurer U, Charvet C, Wagman AS, Dejardin E, Green DR: Glycogen synthase kinase-3 regulates mitochondrial outer membrane permeabilization and apoptosis by destabilization of MCL-1 Mol Cell 2006;21:749-760.

75 Nie H, Xue X, Li J, Liu X, Lv S, Guan G, Liu H, Liu G, Liu S, Chen Z: Nitro-oleic acid attenuates OGD/R-triggered apoptosis in renal tubular cells via inhibition of Bax mitochondrial translocation in a PPAR-gammadependent manner. Cell Physiol Biochem 2015;35:1201-1218.

76 Gomez L, Thiebaut PA, Paillard M, Ducreux S, Abrial M, Crola Da Silva C, Durand A, Alam MR, Van Coppenolle F, Sheu SS, Ovize M: The SR/ER-mitochondria calcium crosstalk is regulated by GSK3beta during reperfusion injury. Cell Death Differ 2016;23:313-322.

-77 Cai L, Li Y, Zhang Q, Sun H, Yan X, Hua T, Zhu Q, Xu H, Fu H: Salidroside protects rat liver against ischemia/ reperfusion injury by regulating the GSK-3beta/Nrf2-dependent antioxidant response and mitochondrial permeability transition. Eur J Pharmacol 2017;806:32-42.

-78 Xie Y, He Y, Cai Z, Cai J, Xi M, Zhang Y, Xi J: Tauroursodeoxycholic acid inhibits endoplasmic reticulum stress, blocks mitochondrial permeability transition pore opening, and suppresses reperfusion injury through GSK-3ss in cardiac H9c2 cells. Am J Transl Res 2016;8:4586-4597.

79 Cohen P, Frame S: The renaissance of GSK3 Nat Rev Mol Cell Biol 2001;2:769-776.

80 Dai P, Mao Y, Sun X, Li X, Muhammad I, Gu W, Zhang D, Zhou Y, Ma J, Ni Z, Huang S: Attenuation of Oxidative Stress-Induced Osteoblast Apoptosis by Curcumin is Associated with Preservation of Mitochondrial Functions and Increased Akt-GSK3beta Signaling. Cell Physiol Biochem 2017;41:661-677.

81 Zeng W, Zhang W, Lu F, Gao L, Gao G: Resveratrol attenuates MPP+-induced mitochondrial dysfunction and cell apoptosis via AKT/GSK-3beta pathway in SN4741 cells. Neurosci Lett 2017;637:50-56.

-82 Hu Y, Li L, Yin W, Shen L, You B, Gao H: Protective effect of proanthocyanidins on anoxia-reoxygenation injury of myocardial cells mediated by the PI3K/Akt/GSK-3beta pathway and mitochondrial ATP-sensitive potassium channel. Mol Med Rep 2014;10:2051-2058. 


\section{Cellular Physiology Cell Physiol Biochem 2017;44:1445-1459 \\ \begin{tabular}{l|l|l}
\hline and Biochemistry 10.1159/000485580 & $\begin{array}{l}\text { C } 2017 \text { The Author(s). Published by S. Karger AG, Basel } \\
\text { www.karger.com/cpb }\end{array}$ \\
\hline
\end{tabular}}

Yang et al.: Roles of GSK-3 $\beta$ in Mitochondria

83 Huang X, Zuo L, Lv Y, Chen C, Yang Y, Xin H, Li Y, Qian Y: Asiatic Acid Attenuates Myocardial Ischemia/ Reperfusion Injury via Akt/GSK-3beta/HIF-1alpha Signaling in Rat H9c2 Cardiomyocytes. Molecules 2016;21.

84 Zheng Y, Zhang WJ, Wang XM: Triptolide with potential medicinal value for diseases of the central nervous system. CNS Neurosci Ther 2013;19:76-82.

-85 Wang W, Yang Y, Xiong Z, Kong J, Fu X, Shen F, Huang Z: Inhibition of glycogen synthase kinase 3beta ameliorates triptolide-induced acute cardiac injury by desensitizing mitochondrial permeability transition. Toxicol Appl Pharmacol 2016;313:195-203.

-86 Cheng Y, Xia Z, Han Y, Rong J: Plant Natural Product Formononetin Protects Rat Cardiomyocyte H9c2 Cells against Oxygen Glucose Deprivation and Reoxygenation via Inhibiting ROS Formation and Promoting GSK3beta Phosphorylation. Oxid Med Cell Longev 2016;2016:2060874.

87 Wang D, Liu L, Zhu X, Wu W, Wang Y: Hesperidin alleviates cognitive impairment, mitochondrial dysfunction and oxidative stress in a mouse model of Alzheimer's disease. Cell Mol Neurobiol 2014;34:1209-1221.

-88 Teng L, Meng Q Lu J, Xie J, Wang Z, Liu Y, Wang D: Liquiritin modulates ERK and AKT/GSK3betadependent pathways to protect against glutamateinduced cell damage in differentiated PC12 cells. Mol Med Rep 2014;10:818-824.

89 Kwon SH, Ma SX, Lee SY, Jang CG: Sulfuretin inhibits 6-hydroxydopamine-induced neuronal cell death via reactive oxygen species-dependent mechanisms in human neuroblastoma SH-SY5Y cells. Neurochem Int 2014;74:53-64.

90 Huang HH, Shao ZH, Li CQ, Vanden Hoek TL, Li J: Baicalein protects cardiomyocytes against mitochondrial oxidant injury associated with JNK inhibition and mitochondrial Akt activation. Am J Chin Med 2014;42:7994.

-91 Jo SJ, Choi SJ, Yoon SY, Lee JY, Park WS, Park PJ, Kim KH, Eun HC, Kwon O: Valproic acid promotes human hair growth in in vitro culture model. J Dermatol Sci 2013;72:16-24.

-92 Kreisl TN, Kotliarova S, Butman JA, Albert PS, Kim L, Musib L, Thornton D, Fine HA: A phase I/II trial of enzastaurin in patients with recurrent high-grade gliomas. Neuro Oncol 2010;12:181-189.

93 Liu CW, Yang F, Cheng SZ, Liu Y, Wan LH, Cong HL: Rosuvastatin postconditioning protects isolated hearts against ischemia-reperfusion injury: The role of radical oxygen species, PI3K-Akt-GSK-3beta pathway, and mitochondrial permeability transition pore. Cardiovasc Ther 2017;35:3-9.

-94 Zhu H, Ding Y, Xu X, Li M, Fang Y, Gao B, Mao H, Tong G, Zhou L, Huang: Prostaglandin E1 protects coronary microvascular function via the glycogen synthase kinase 3beta-mitochondrial permeability transition pore pathway in rat hearts subjected to sodium laurate-induced coronary microembolization. Am J Transl Res 2017;9:2520-2534.

95 Bai F, Guo F, Jiang T, Wei H, Zhou H, Yin H, Zhong H, Xiong L, Wang Q: Arachidonyl-2-Chloroethylamide Alleviates Cerebral Ischemia Injury Through Glycogen Synthase Kinase-3beta-Mediated Mitochondrial Biogenesis and Functional Improvement. Mol Neurobiol 2017;54:1240-1253.

96 Wu JH, Zhang SH, Gao FJ, Lei Y, Chen XY, Gao F, Zhang SJ, Sun XH: RNAi screening identifies GSK3beta as a regulator of DRP1 and the neuroprotection of lithium chloride against elevated pressure involved in downregulation of DRP1. Neurosci Lett 2013;554:99-104.

-97 Huang S, Wang Y, Gan X, Fang D, Zhong C, Wu L, Hu G, Sosunov AA, McKhann GM, Yu H, Yan SS: Drp1mediated mitochondrial abnormalities link to synaptic injury in diabetes model. Diabetes 2015;64:17281742.

-98 Zhou X, Wang HY, Wu B, Cheng CY, Xiao W, Wang ZZ, Yang YY, Li P, Yang H: Ginkgolide K attenuates neuronal injury after ischemic stroke by inhibiting mitochondrial fission and GSK-3beta-dependent increases in mitochondrial membrane permeability. Oncotarget 2017;8:44682-44693

99 Li H, Zhang C, Sun W, Li L, Wu B, Bai S, Li H, Zhong X, Wang R, Wu L, Xu C: Exogenous hydrogen sulfide restores cardioprotection of ischemic post-conditioning via inhibition of $\mathrm{mPTP}$ opening in the aging cardiomyocytes. Cell Biosci 2015;5:43.

100 Wang S, Zhang F, Zhao G, Cheng Y, Wu T, Wu B, Zhang YE: Mitochondrial PKC-epsilon deficiency promotes I/R-mediated myocardial injury via GSK3beta-dependent mitochondrial permeability transition pore opening. J Cell Mol Med 2017;21:2009-2021. 